\title{
Rebels in Biblical and Chinese Texts: A Comparative Study on the Interplay of Myth and History ${ }^{+}$
}

\author{
Aryeh Amihay ${ }^{1, *}$ and Lupeng $\mathrm{Li}^{2, *}$ \\ 1 Department of Religious Studies, University of California, Santa Barbara, CA 93106, USA \\ 2 School of Foreign Languages, Xidian University, Xi'an 710126, China \\ * Correspondence: aryeh.amihay@gmail.com (A.A.); lupengli@xidian.edu.cn (L.L.) \\ + We collaborated on this study while Lupeng Li was a visiting scholar at University of California, \\ Santa Barbara, enabled by the China Scholarship Council (CSC). We are grateful to the CSC and to \\ Fabio Rambelli, chair of the Department of Religious Studies at UCSB, for their support. At our early stages \\ of research, we were fortunate to receive advice and encouragement from Shadi Bartsch-Zimmer, Jianshu \\ Liu, and Lydia Lee. We thank them all, as well as the anonymous readers for the journal.
}

Received: 27 July 2020; Accepted: 16 October 2020; Published: 1 December 2020

\begin{abstract}
This study offers a new approach for studying biblical myth in two directions: first, by expanding the scope of investigation beyond the clearly mythological elements to other areas of biblical literature, and second, by drawing comparisons to classical Chinese literature. This article thus reconsiders the relationship between myth and history in both biblical and Chinese literature, while seeking to broaden the endeavor of the comparative method in biblical studies. Two examples are offered: (1) the story of Moses's call narrative and his relationship with Aaron in Exodus in light of the story of Xiang Liang and Xiang Ji in the Shiji; (2) the story of Saul and David in 1 Samuel compared with the story of Dong Zhuo and Lü Bu in the Romance of the Three Kingdoms. Both comparisons demonstrate the operation of Claude Lévi-Strauss's inversion principle. Conclusions regarding each of these literatures are presented separately, followed by cross-cultural insights and shared aspects in the study of myth, historiography, and religion.
\end{abstract}

Keywords: comparative religion; Hebrew Bible; Chinese classics; Shiji; Romance of the Three Kingdoms; Moses; David; rebels; myth

\section{Introduction: Myth and History}

Much of the study of myth in the Hebrew Bible tends to focus on the primordial history of the world, namely Genesis 1-11 and parallels, ${ }^{1}$ and the patriarchal narratives of Genesis more broadly. ${ }^{2}$ The modern rise of skepticism in regards to the historicity of those narratives caused them to be re-assessed as bearing a universal value that transcends historical narrative, intertwining primeval themes of violence, sex, and family. This also entailed a common distinction often intuited in scholarship, and at times explicitly articulated, that there is a distinction between myth and history. In other words, that if a narrative manifests a historical plausibility, it is less likely to be mythical. At times, this distinction also included a religious bias seeking to separate "Israelite History from Pagan myth", as J. J. M. Roberts potently describes the alignment. He proceeds to argue against such a distinction, recognizing "the possible mythological use of history as well as the historical use of myth". ${ }^{4}$ Similarly,

\footnotetext{
See, for example, Fishbane (2005); Ballentine (2015); Tugendhaft (2018); Gelander (2018); Cho (2019).

e.g., Steinmetz (1991); Kunin (1995); Segal (2012).

(Roberts 1976, p. 1; reprinted in Roberts 2002, p. 59); cf. Collins (1979); Tsevat (1980, pp. 177-87).

(Roberts 1976, p. 13; reprinted in Roberts 2002, p. 71); See also (Roberts 1973; reprinted in Roberts 2002, pp. 313-30).
} 
Qinghe Liu emphasized the need to recognize the incorporation of myth into historiography while acknowledging the historical traces that are left as residue in myth. ${ }^{5}$ This recognition should help avoid binaries established with the advent of secularism and the debate over biblical literalism that tend to conflate historicity with validity or significance. ${ }^{6}$

The following study draws on the blurring of the lines between myth and history and proposes an expansion of research on biblical mythmaking through two steps. The first step is achieved by discussing a theme that appears both in a story that is decidedly mythological (through its engagement with the supernatural) and a story that is at least historically plausible (in that it is predominantly reliant on human agency). The two case studies are the story of Moses and the story of David and the shared motif of rebellion that connects them. The second step is the choice to discuss these two biblical stories through a comparison of classic Chinese texts. Their respective parallels are drawn from the Chinese classics Records of the Grand Historian, or Shiji (史記) and The Romance of the Three Kingdoms (三國演義). Just as with the two biblical narratives examined, these texts are classified as historiography and historical fiction, respectively, and just as is the case with the biblical texts, drawing the line between these two categories is far from simple. The comparison offered below does not seek to compare the more mythical narrative of Moses with the historical fiction of the Three Kingdoms and the historiographic narrative of the Books of Samuel with the Shiji. Instead, we pair the Shiji with the Exodus narrative and the Books of Samuel with the Three Kingdoms, thus further blurring the lines between myth and history. Since an appeal to Chinese classics is not a common course for comparative research in biblical studies, our rationale in this study requires some background and contextualization.

\section{Chinese Literature and the Comparative Method in Biblical Studies}

Comparative approaches to the study of the Hebrew Bible can be broadly divided into two trajectories: one direction is looking forward, namely, the study of "reception history" or "biblical exegesis," covering a broad scope of literatures ranging from ancient Judaism and early Christianity, to modern literature and film. ${ }^{7}$ The other direction is backward looking, focusing on the Near Eastern context of the Hebrew Bible. ${ }^{8}$ Indeed, this direction in research was called in its early days "the comparative method," as if the only relevant comparison for the study of the Hebrew Bible is the backdrop of the Near East. Shemaryahu Talmon, for example, praises the comparative method, when it is "historically and geographically defined" for its success in removing "biblical Israel from the cultural and conceptual seclusion" that was previously imposed on it. ${ }^{9}$ In a foundational methodological paper on the comparative method, he does not consider a single case, or even the option, of the benefits of comparison outside civilizations who were in close proximity to ancient Israel in time and place.

But even for this limited scope of comparison, confined to the Near East, Talmon offers many cautions and limitations, lamenting his colleagues' "disregard for internal analysis as a means to elicit from the biblical literature itself" relevant concepts for their study. ${ }^{10}$ Such qualms were most strongly expressed in Samuel Sandmell's oft-cited article "Parallelomania", where he warned against

5 Liu (1987).

6 For the secular context of this debate, see Taylor (2007, pp. 261-69, 322-27). Against a naïve reading that expects historicity for validity, consider Ninian Smart's tantalizing challenge: "Does Anna Karenina suffer from being fictional, over against a biography of Brezhnev?" See Smart (1996, p. 130).

7 The study of reception history is vast, and its broad range can be gleaned from the ongoing publication of the Encyclopedia of the Bible and Its Reception by de Gruyter (beginning with Klauck 2009), alongside its accompanying newly-founded Journal of the Bible and Its Reception. For major methodological considerations see Lieb et al. (2011); England and Lyons (2015); Breed (2014). Some examples for reception history studies include Mulder (1988); Kugel (1998); Hendel (2010); Baden (2019).

8 This too is exceedingly vast to be presented here properly. For a helpful brief survey of biblical studies and Near Eastern literature, see Chavalas (2011). For further methodological issues see Cross (1973); Malul (1990); Greenspahn (1991); Nissinen (2000); Niditch (2016).

9 Talmon (1993, p. 17).

10 Talmon (1993, p. 23). 
comparisons leading to "some pallid unanimity" and describing the entire method as a "disease". ${ }^{11}$ Although his attack was directed at postbiblical literature, his diatribe resonated with many biblical scholars and had a substantial impact on inhibiting comparison. ${ }^{12}$

Broader approaches to comparative studies in biblical scholarship often entailed an appeal to the Greco-Roman world. As can be seen in the pioneering work of Cyrus Gordon, Michael Astour, and later Moshe Weinfeld, and more recently in the studies of Guy Darshan and Bruce Louden, these reflect a broadening of the scope while maintaining the principle. ${ }^{13}$ They offer a new delineation of the region or vicinity of the biblical world, valuably challenging orientalist definitions of space and culture, but nevertheless bolster the notion that comparison necessitates a point of contact and ultimately a determination on issues of dependence and influence.

The need for comparison of biblical texts with cultures that were not in contact with the civilizations that produced the Bible should thus be self-evident. It is an entirely new path that has gained little attention in biblical scholarship, and more so in the so-called Western world. The purpose of such an enterprise is not to search for origins or to uncover influences, but rather to gain fresh insights by noting resemblances between distant texts. By definition, such insights will not include claims of dependence. Furthermore, we also contend that this project is timely as the world is advancing towards a global village, with a greater awareness not only of the rewards of cross-cultural comparison but for the need to destabilize and question hegemonic Eurocentric paradigms that dominate scholarship. ${ }^{14}$

Perhaps for obvious reasons, much of the comparative work that has been done between biblical literature and other world cultures is conducted in non-Western cultural contexts, and consequently there is less material in English on these topics. ${ }^{15}$ Thus we find for example, CISMOR-the Center for Interdisciplinary Study of Monotheistic Religions_-at Doshisha University in Kyoto, Japan, and the Center for Judaic and Inter-Religious Studies of Shandong University, in Jinan, China. A notable early exception in Western scholarship is Barbara Holdrege's monograph, Torah and Veda, although her study construes the Jewish tradition more broadly than a focus on the biblical corpus alone. ${ }^{16}$ A similar example is Vanessa Sasson's comparison of Jewish and Buddhist birth narratives. ${ }^{17}$ Charles Trimm has offered comparisons between China and the ancient Near East, and between the latter and the Hebrew Bible, but has yet to offer a study that will draw direct comparisons between biblical and Chinese texts. ${ }^{18}$ Studies of a more limited scope focused on historiography, scribal practices, redactional processes, and ethics, ${ }^{19}$ but the majority of research published in English is concerned with reception history, i.e., in the reception of the Bible in non-Western countries. ${ }^{20}$ In Chinese scholarship, where these endeavors are more common, we do find a wider selection of comparative studies that focus on biblical texts, however they are often limited in scope. Thus, Ertai Ah suggests some similarities between the myths of creation in the Hebrew Bible and Mongolian mythology, as well as identifying a common flood myth. ${ }^{21}$ Yanyong Zhang compares the concept of filial piety in biblical and Confucian texts. ${ }^{22}$ Jianqing Hu explored similarities of love songs in both traditions. ${ }^{23}$

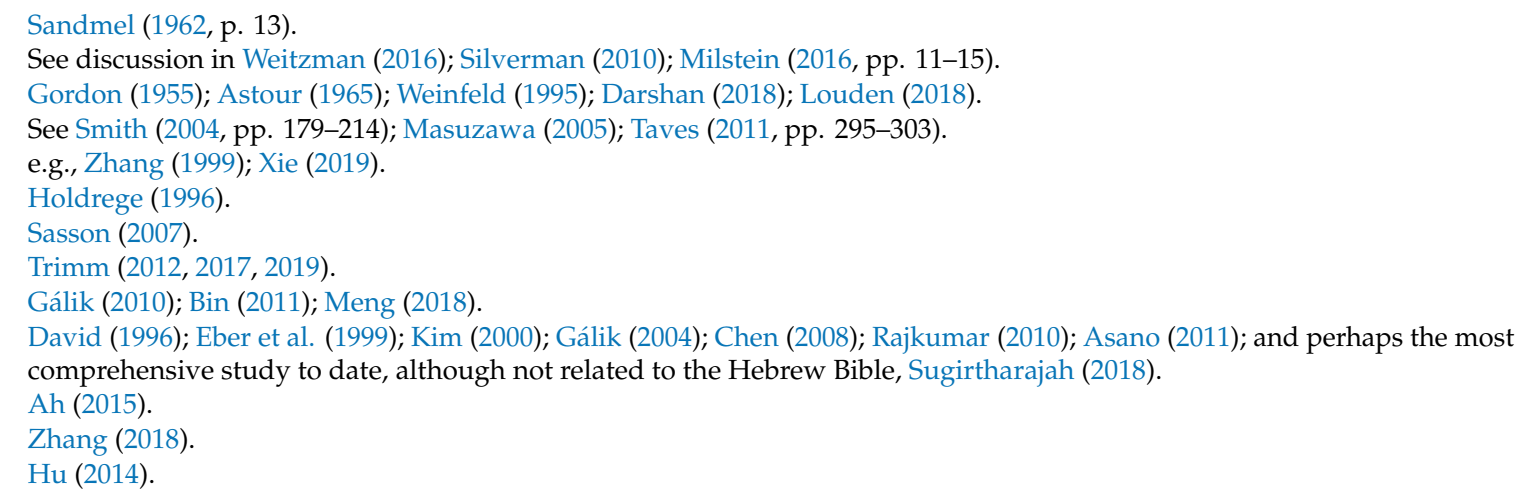


Although contact between European and Chinese cultures developed fairly early in the modern period, with travel during the Renaissance, Sinology developed slower than the oriental fields of the Near East, a difference usually ascribed to a religious prejudice. ${ }^{24}$ Possibly for the same reason, pioneering sinologists who were biblically literate by virtue of their education and persuasion offer sporadic comparisons to biblical texts throughout their writings, but never in the form of a systematic study. ${ }^{25}$ Our purpose here is first and foremost to fill that gap and to advocate for further comparative studies in the same vein.

In recent years, Western comparative studies in antiquity have increased substantially, with a focus on Greco-Roman history and culture in the West and comparisons to China in the East. ${ }^{26}$ The development of cross-cultural studies has effectively redefined the process of comparative studies, with insights borne of collaboration, to further confront an assumption that one culture is the point of reference, while the other is compared inasmuch as it can fit to measure. In the poignant words of Hans-Georg Gadamer, "when two people understand each other, this does not mean that one person 'understands' the other". ${ }^{27}$ The departure point of a comparative endeavor must be on equal footing for both sides of the comparison. As several scholars have emphasized, this type of research serves to work against the biases of authors who assumed, especially in antiquity, that their own culture was superior to any other. ${ }^{28}$

The dangers of comparison are indeed very real and must be acknowledged. A distinction should be drawn between a comparison of civilizations who certainly had or may have had contact and cultural exchange, and between civilizations where no such contact is hypothesized. Talmon's emphasis that comparatists should "pay heed to differences between cultures and not only to likenesses" 29 is one that is commonly accepted, as is his warning against comparison on a "grand scale". ${ }^{30}$ Comparisons require a cautious examination of specific details rather than listing superficial similarities. They are most fruitful when they acknowledge both similarities and contrasts, and they should not aim at creating an "eclectic museum," as Walter Kaufmann described it, ${ }^{31}$ of dazzling semblances. One more caution should be noted: comparisons should not be made for the sake of advancing a theological agenda, in favor or against a tradition, as in the sordid affair of Friedrich Delitzsch, or the subtler prejudice of Mircea Eliade. ${ }^{32}$ The endeavor of comparison can only be worthwhile from a respectful perspective that seeks to embrace and learn from all its objects of study.

\section{Neo-Structuralism and the Comparative Method in Biblical Studies}

In a prior study, ${ }^{33}$ Aryeh Amihay proposed to study biblical myth through Claude Lévi-Strauss's formula of inversion for the analysis of relations between various myths, ${ }^{34}$ and to assist in distinguishing the biblical phenomenon of deliberate "mirror narratives" 35 from the structural development of other kinds of similarities between independent narratives. A palpable lacuna of Amihay's study was that all the examples were from texts that were written in the Middle East, in cultures that came into contact with one another, whereas Lévi-Strauss's claim is that the structure of myth is universal and not only

\footnotetext{
Zurndorfer (1995, pp. 4-44).

25 See, for example, Kidd (1841, pp. 41-44, 358); Legge (1882, pp. 233, 340; 1885a, pp. 239, 417; 1885b, p. 115); Waley (1937, p. 26).

26 See, for example, Jullien (2000); Scheidel (2009); Denecke (2014); Lloyd (2014). An earlier example is Raphals (1992). As with biblical comparisons, cross-cultural interest is also expressed through the investigation of reception history. See, for example, Bartsch (2013).

27 Gadamer (Gadamer 2004, p. 355).

28 Zhang (2010, pp. 3-28); Shankman and Durrant (2002, pp. 1-6). See also Douglas (2009, pp. 30-32); Spivak (2012).

Talmon (1993, p. 47).

Ibid., 48.

Kaufmann (1958, pp. 405-7).

For the former, see Larsen (1995); for the latter, see Allen (2002, pp. 101-27).

Amihay (2018).

(Lévi-Strauss 1955; reprinted in Lévi-Strauss 1963, pp. 206-31).

35 A term coined by Yair Zakovitch in his seminal study (Zakovitch 1985, pp. 165-76). For an English summary see Amihay (2018, p. 561).
} 
can but should be studied through examples of distant cultures. The comparative exploration in this study seeks to supplement Amihay's previous arguments, while offering further comments on the study of myth in the Hebrew Bible.

While the previous arguments need not be repeated here, they inform the main assumptions of what follows: firstly, an affirmation of a shared universal experience, that resurfaces in various cultures. Second, that this universality is decisive in shaping stories, no less than authorial intent. Thirdly, that recognizing this structuralist tendency can account not only for similarities but also for differences in stories. These three assumptions also question the insistence on a search for influence in comparative biblical studies, and thus raise a theoretical contribution to comparative research at large.

\section{Rebels and Rivals: Moses and Aaron in Light of Xiang Liang and Xiang Ji}

The Shiji, also known in English as The Records of the Grand Historian, is the founding text of Chinese historiography. Its author, Sima Qian (c. 145 BCE-86 BCE), has been dubbed "The Father of Chinese History", 36 despite the fact that this is not the first work of history in Chinese literature, and is most notably preceded by Chunqiu, or The Spring and Autumn Annals, of the Confucian Five Classics. ${ }^{37}$ The work is divided into five thematic sections, covering a history that spans about three millennia up to the date of its purported author. The work, however, has long been recognized to be composite with several styles incorporated in it. ${ }^{38}$ Likewise, the question of Sima Qian's reliability and the historicity of details of the work are treated with greater skepticism in scholarship. ${ }^{39}$ The first of the five sections is called the Annals (本紀), and the following narrative is quoted from the seventh Annal, Xiang Yu, which begins with the story of Xiang Ji (also named Xiang Yu) and his uncle Xiang Liang:

Xiang Liang killed a man. He and Xiang Ji fled from vengeance to the seat of Wu [Commandery]. None of the officers of Wu were as worthy as Xiang Liang. Whenever there was a great levy of corvée labor or a funeral in $\mathrm{Wu}$, Xiang Liang always took charge of matter on behalf [of the local people]. Secretly he organized and trained his guests, retainers and other young men in the arts of war, and in this way he came to know their abilities.

When the First Emperor of Qin traveled to Kuaiji, both Xiang Liang and Xiang Ji looked on as he crossed the Che River. Xiang Ji said: "I could take that fellow's place". Xiang Liang covered Ji's mouth with his hand, saying, "Don't talk nonsense or all our clan will be executed!" But because of this, Xiang Liang looked at Ji in a different light. ${ }^{40}$

The text then describes the governor of Kuaiji preparing for war. Following the death of the emperor, the governor fears unrest, and tells Xiang Liang, "I have heard it said: Move first and you will gain control; move last and you will be controlled". He seeks a warrior named Huan Chu who is in hiding, and Xiang Liang tells him that only his nephew, Xiang Ji, knows the whereabouts of Huan Chu. The story continues:

Xiang Liang then went out and instructed Xiang Ji to stay outside and wait with his sword in hand. Xiang Liang went in, sat with the governor again, and said: "I would ask you to call in Xiang Ji and have him receive your order to summon Huan Chu".

The governor said: "very well".

Xiang Liang called Xiang Ji in. After a while, Xiang Liang signaled Xiang Ji, as if to say: "you may act now!"

36 On the epithet, see Teng (1961); Stuurman (2008, pp. 4-10).

37 For Confucian influence on Sima Qian see Durrant (1995, pp. 29-69); Lewis (1999, p. 140); Nienhauser (2007); Kern (2015).

38 See Hulsewé (1975); Hardy (1994); Durrant (1995, pp. xi-xx); Kern (2003); Klein (2019, pp. 1-76).

39 Nylan (Nylan 1998-1999); Olberding (2012, pp. 1-38); Klein (2019, pp. 259-332).

40 Translation is based, with minor changes, on Nienhauser (1994, p. 180). 
At this, Xiang Ji drew his sword and cut off the governor's head. Xiang Liang held up the governor's head and hung the seal and sashes [of office] from his belt. Governor's attendants were stunned and thrown into confusion. Xiang Ji struck down almost a hundred of them. The whole office lay prostrate in fear, none of them daring to rise. ${ }^{41}$

The scene of the clandestine beheading evokes several biblical narratives, resembling most closely the iconic scene of Judith and Holofernes from the Apocrypha, but possibly also reminiscent of Yael's killing of Sisera or Goliath's beheading by David. Nevertheless, we propose a comparison to Moses's narrative prompted by Xiang Liang's initial homicide and flight. The background of the killing is opaque, but a previous detail claiming he was implicated in a case might suggest certain circumstances that justified the killing, an implication that is perhaps more manifest in Moses's narrative (Ex 2:11-15). ${ }^{42}$

The comparison that follows does not equate Xiang Liang with the significance of Moses in any way. His death is succinctly reported shortly after he rises to power, ushering the rise of his nephew, who only enjoyed a short-lived reign. ${ }^{43}$ The comparison is between the two narrative units and their analogous structure. Furthermore, comparing Moses to a rebel or a usurper does not highlight the features most commonly associated with him, since his objection to Pharaoh is naturally framed in terms of overall Israelite history, of the injustice of slavery, and so forth. Nevertheless, this aspect of Moses has been acknowledged, and not only for twentieth-century cinematic purposes, but since ancient times. ${ }^{44}$

The key to interpreting this narrative is found in the words of the governor to Xiang Liang: "move first and you will gain control; move last and you will be controlled". This major principle of strategic thinking, which strategists tend to agree does not always prove right, ${ }^{45}$ is both exemplified and subverted in the narrative. Xiang Liang prevents his nephew Xiang Ji from moving first, when Xiang Ji expresses his will to attack the emperor, and he later signals to him to make a move against the governor, after the emperor has died. There are further considerations involved here other than the "first move" principle alone, most notably the object of the attack and its timing. By choosing a less powerful target, and hence also a more modest goal (rather than the more ambitious desire to seize control over the empire in its entirety), especially when this target is most vulnerable, Xiang Liang is able to ensure their success. Xiang Liang and Xiang Ji are also the ones to make the first move against the governor, in this context. However, Xiang Ji's ambition sought to place himself in power, and his first proposal was symbolically rejected. When the proposal of a rebellion is raised a second time, Xiang Ji is the one who executes the plan, but the power is gained by his uncle. While it will eventually change, at this point in the narrative, perhaps also due to his age, Xiang Ji foregoes his chance to seize power by a first move, conceding to the superiority of his uncle. The connection between the two scenes is encapsulated in the fact that his uncle covers Ji's mouth when he speaks, but then speaks himself to instigate the attack.

The story thus sets two pairs with external and internal contestations of power: on the one hand, the emperor and the governor, on the other, Xiang Liang and Xiang Ji. The first member of the first pair remains untouched, while the latter is defeated by the counterpart pair. At the same time, the pair of rebels presents an internal rivalry over power, however subtle, that runs parallel to their unified front in the external circle. This dynamic is also present through the theme of sibling rivalry in the story

41 Ibid.

42 See Meyers (2005, p. 44), who argues that Moses's violence is equated with God's violence towards the Egyptians, and hence viewed as justified in the terms of the biblical author.

43 Klein (2019, pp. 360-65).

44 Most notably, in the tale of the infant Moses removing the crown from Pharaoh's head, first reported by Josephus (Jewish Antiquities 2.234). See further in Amihay (2018, pp. 569-70). For later use of this dramatic motif in Moses's characterization in modern film, see Koosed (2016).

45 For the preponderance of this principle in both military and business strategy as well as its shortcomings, see von Clausewitz (1976, pp. 198-201, 357-71, 523-27); Hausken (2011); Kerin et al. (1992); Magee et al. (2007). 
of Moses and Aaron. ${ }^{46}$ The appointment of Aaron to serve as Moses's mouth appears after Moses has angered God in his refusal to accept the mission (Ex 4:13-15). ${ }^{47}$ A tension concerning the status of Moses in relation to Aaron runs through the narrative, as Moses is first designated to be a God unto Aaron (Ex 4:16), but then a God unto Pharaoh with Aaron as Moses's prophet (Ex 7:1). On the other hand, Moses is not to speak to Pharaoh directly, but only through Aaron (Ex 7:2). The miracles that astound Egypt are performed by Aaron (Ex 7:10-12, 20-22), but only upon Moses's command $($ Ex 7:9, 19). The later tradition of the Golden Calf could cast Aaron as a usurper, who is eager to replace Moses. ${ }^{48}$ The prevalence of this aspect of Moses's and Aaron's relationship is also seen in Aaron's alliance with Miriam against Moses in Num 12:1-13. ${ }^{49}$ Subsequent Jewish commentary expounds on this theme in various ways. A rabbinic text describes Moses requesting his death will be as grand as Aaron's, showing Moses to be envious of Aaron's honor (avot deRabbi Nathan A 12), and Nachmanides notes that scripture reports that Aaron kissed Moses, but not that they kissed one another (Ex 4:27), "since Moses the humble one treated his older brother with respect". Regardless of the validity of Nachmanides's interpretation at this point, the concern for the honor between the brothers demonstrates the persistence of a theme of sibling rivalry.

Table 1 exemplifies the parallel structure of relationships between the two narratives:

Table 1. Hierarchical Division of Rulers and Rebels.

\begin{tabular}{ccc}
\hline Function & Shiji & Hebrew Bible \\
\hline (1) Higher Ruler & Emperor of Qin & God \\
(2) Lower Ruler & Governor of Kuaiji & Pharaoh \\
(3) Senior Rebel & Xiang Liang & Moses \\
(4) Junior Rebel & Xiang Ji & Aaron \\
\hline
\end{tabular}

The parallel of a human Emperor and the biblical God requires some explanation: the equation itself is not a problem, as each is the prime ruler of the given narrative and thus serves that function within the structure of the unit. The problem lies in the alignment of God and Pharaoh: their distinction as divine and human is also not a major problem, both because God is often described in terms of kingship in the Hebrew Bible, ${ }^{50}$ and because the Pharaohs were treated as deities in ancient Egypt. ${ }^{51}$ It is plausible that to early audiences of the Exodus narrative, the battle between God and Pharaoh would have been construed as a mythic battle between deities. ${ }^{52}$ The structural problem arises, however, from the fact that in the biblical narrative these two rulers are not allies of the same camp, but adversaries, in contrast to the structure of the paradigm in the Shiji narrative. This is indeed a problem, to be addressed below.

46 The motif of sibling rivalry between Moses and Aaron relates to the biblical narrative as formed and received, regardless of evidence that their identification as brothers is a later development, unattested in the earlier strata of the narrative. See Dozeman (2009, pp. 143-45).

47 Traditional Jewish commentators were at pains to argue that Moses does not show any disrespect to God in his request in Exod 4:13. Nachmanides, for example, when commenting on this verse, attributes the hesitation to Moses's renowned humility (Num 12:3). Yet several still view Aaron's mention at this point as retribution for Moses's reluctance. Thus Exodus Rabbah 3.17 says that this is when God decided to give the priesthood to Aaron rather than Moses (cf. Rashi on Ex 4:14). See also Propp (1999, p. 209).

48 For another aspect of a rivalry between Moses and Aaron in the Golden Calf episode, see Assmann (1997, p. 253, n. 17). Conversely, it could be said that Moses's initial reluctance to lead ultimately results in a future downfall of the people. See Propp (1999, p. 213): “Still, the deputation of Aaron is in some sense a punishment, a diminution of Moses' dignity. In fact, all Israel will suffer, since Aaron will construct the Golden Calf."

49 On the sophisticated portrayal of rivalry between Moses and Aaron in this unit, see Milgrom (1990, pp. 94, 97).

50 e.g., Ex 15:18; 1 Sam 8:7; Isa 6:4; Ob 21; Ps 24:9-10, 29:10, 47:3, 93:1. cf. Moore (2009); Flynn (2013); Wilson (2017, pp. 188-98).

51 Payne (1964, pp. 20-63); Hare (1999, pp. 34-43); Quack (2010); Collins (2014).

52 See Propp (1999, pp. 34, 554-59); Guillaume (2004); Brevard Childs reads theology into the defeat of Pharaoh as paradigmatic of the "eschatological battle between God and Satan" and the antichrist (Childs 1974, p. 169). Dozeman (2009, p. 111) stresses that for the P narrative, at least, the purpose of the conflict is to bring the knowledge of Yahweh to the Egyptians (Ex 7:5). 
Recognizing the quadruple structure of the narrative, its parallel transactions can be summarized in these three points:

- (3) kills a person

- (3) and (4) challenge the power of (2)

- (2) dies, leading (3) to be the higher ruler of the lower pair

In regards to the "first move" principle mentioned above, it should be noted that Xiang Ji eventually seizes power with the passing of Xiang Liang. Similarly, while Moses is considerably a more important leader than Aaron within the wilderness narrative, subsequent Israelite history will give far more power to the descendants of Aaron in the priesthood over the descendants of Moses. ${ }^{53}$ The major differences between the narratives are also crucial for our structural analysis, as summarized in Table 2:

Table 2. Divergent transactions of parallel narratives.

\begin{tabular}{|c|c|c|}
\hline Event & Shiji & Hebrew Bible \\
\hline - Initial threat to power & - $\quad$ (4) desires to undermine (1) & - (1) sends (3) to undermine (2) \\
\hline - Response to threat & - In response, (3) rebukes (4) & $\begin{array}{l}\text { - In response, (3) demurs, and } \\
\text { (1) sends (4) to join him }\end{array}$ \\
\hline - Ultimate downfall & $\begin{array}{l}\text { - Later, (3) gives (4) orders to } \\
\text { kill (2) }\end{array}$ & $\begin{array}{l}\text { - }(1) \text { kills (2), in action } \\
\text { conducted by (3) }\end{array}$ \\
\hline
\end{tabular}

The list of differences between the stories allows one to see Lévi-Strauss's inversion principle in action. Presented as a mathematical formula, it claims that an omitted element from one version of a myth will subsequently reappear in the myth's parallel but in an inverted function. Both Xiang Liang and Moses are presented as contesting the rule of law in the outset of the narrative through homicide. At the same time, neither of them present an interest in directly challenging the governing power. The desire of the usurper, manifested in the Shiji, is transformed into a commandment imposed upon him, presented by God, the supreme ruler (the supreme ruler being the object of the initial threat in the Chinese narrative). Subsequently, the death of Pharaoh is brought on by God, although with Moses's agency as holding the rod against the water (Ex 14:26-31). This significant difference works both on the structural level, as demonstrated through this comparison, but also serves a theological purpose, highlighting God's power against human power. Recognizing that the author might even wish to stress the weakness of God's human agents ${ }^{54}$ helps to reassess the realignment of God in the paradigm proposed above, and the ways in which his agents who are rebelling against Pharaoh are also in some sense rivals of God who tend to defy him (Num 20:12, 24; 27:14).

It is conspicuous that at the outset of the plagues, God commands Moses to tell Aaron to use the rod, emphasizing the limitation of Moses's agency as a consequence of Moses's initial hesitation. However, in the scene of Pharaoh's death, parallel to the killing of the governor, Aaron is not involved at all. In the Chinese narrative, the senior rebel curtails the initial desire for usurpation, and eventually gives the order to his junior. In the biblical narrative, the initial sentiment is one of hesitation, but it eventually appears with the direct involvement of the senior rebel (rather than the rebel acting by proxy). In the biblical narrative, acting by proxy was a sign for Moses's weakness, whereas in the Shiji it is Xiang Liang's privilege to be giving the orders rather than committing the act himself. Aaron, who was initially brought in as a punishment for Moses, is absent from the scene of the victory.

The inversion is thus complete: protagonist (4), the junior rebel, is absent from the initial scene in Exodus (and is the center of that scene in Shiji). He is also omitted from the third stage of the story,

53 The protracted nature of this rivalry might be indicated by the possible mention of a Mosaic priesthood dynasty in Ju 18:30 (thus Bray 2006, p. 149). See, however, an alternate proposal by Weitzman (1999).

54 Whedbee (1998, p. 187). 
the ultimate downfall. Protagonist (1), the senior ruler, is the object of the threat in the Shiji, but appears in the inverted function of the initiator, or the source of the threat, in Exodus. In the third stage, he is completely absent in the Shiji, and the ultimate victor in Exodus. A glance at Table 2 above, with attention to the positions of all the protagonists at each stage should visually convey the inversion.

Before concluding this comparison, there is one more curious detail to address from Xiang Liang's narrative, by way of demonstrating surprises that occur when searching for comparable narratives. After Xiang Liang rises to power, he receives advice on how to appease the people of Chu:

Xiang Liang thought his suggestion correct and sought out from among the common people a grandson of the late King Huai of Chu, named Xin, who was someone's shepherd. He enthroned him as King Huai of Chu to comply with the wishes of the people. ${ }^{55}$

While our main interest in the narrative was the relationship of Moses and Aaron and how they relate to the external powers they are fighting against, it is remarkable that the story follows with another example of the inversion principle. The element of the senior rebel being a shepherd on someone else's behalf appears in Exodus (Ex 3:1), but is absent in Xiang Liang's story. It appears later on, in an inverted function, combining two elements of the narrative of Moses and Jethro: Moses is the shepherd of his father-in-law's sheep, and it is his father-in-law who recommends to Moses he delegates some of his powers (Ex 18:13-27). For a biblical reader, the mention of the shepherd might sound quite ordinary, but the term is not a common one in the Shiji as it is in the Hebrew Bible. Out of more than half a million characters in the text of the Shiji, the characters designating a shepherd here (牧羊) appear only three times more. ${ }^{56}$ Here is the only instance in the Shiji where these characters denote a person described as herding someone else's sheep, a detail also reported about Moses. This fortuitous aspect is offered not as a proof, but an illustration. The inversion principle is generally not focused on details (such as sheep), but on structures that shape the plot or relationships between characters.

The comparison of a composite mythical narrative such as the Exodus narrative with a historical record of ancient China provides new insights on the dynamic of the relationship of Moses and Aaron, and reveals surprising similarities in structure between texts that truly have no dependence between them. Not only does this serve as an important demonstration of Lévi-Strauss's groundbreaking formula, it also bears implications for the analysis of the biblical text as it stands, and the meaning it has beyond its composite nature. It highlights an understated theme of rivalry between Moses and Aaron, that although subtle, nevertheless resurfaces in various instances of the Pentateuchal narrative and postbiblical traditions. It offers new reasons to appreciate the text as a whole, and to recognize that the redaction process the text underwent did not neutralize its mythical power. Conversely, this comparison contributes to students of the Shiji wishing to read it as not only history, but as a mythical epic, by providing new insights on curious details that appear in the historical account.

\section{The Double Marriage: The Stories of David and Lü Bu}

As a further demonstration of the benefits of such comparisons, we explore parallels between the David cycle and the story of Lü Bu (呂布) from the Romance of the Three Kingdoms (三國演義). This fourteenth-century text is considered an historical novel, meaning it is primarily a work of fiction, relying on historical records. ${ }^{57}$ Its details are often compared against The Records of the Three Kingdoms

55 See Nienhauser (1994, p. 183).

56 Other appearances are in chapter 30, the third category, the treatise on equalization (平準書); and in the fifth category, chapter 111, the Biographies of General Wei and General Piaoji (衛將軍驃騎列傳) and chapter 121, the Biographies of Confucian Scholars (儒林列傳). The Shiji also uses shepherding as a metaphor for leadership (e.g., in chapter 6, 秦始皇本紀, as well as in the mention in chapter 30). The same metaphor appears also in the Jewish tradition in relation to Moses (Exodus Rabbah 2.2).

57 For its date, see the Afterword in Roberts (2020, pp. 389-92). Note, however, Andrew Plaks's argument that the text as exists today is a sixteenth century work (Plaks 1987, pp. 361-495; cf. Li 2007). 
(三國志) of the third century CE, which is considered more historical. ${ }^{58}$ The story discussed here takes place in the early second century CE.

The comparison of a medieval work with a biblical text should not be misconstrued as a departure from our methodology: in principle, we are choosing to compare texts that have not influenced one another, and hence their dating has as little consequence as their provenance or language. While Christianity arrived in China as early as the seventh century CE, it did not gain prominence prior to the sixteenth century. ${ }^{59}$ In any case, there is no indication of Christian or other biblical influences on the Romance of the Three Kingdoms. The text is chosen here because of its mixture of historical figures with fictional details, and the significant role of its stories and their protagonists in Chinese culture. ${ }^{60}$

The epic character of the romance is markedly different from the frugal style of biblical storytelling. Its richness has been said to stand out even in comparison to other Chinese texts. ${ }^{61}$ The legendary nature of the heroes and their actions are employed here for the sake of broadening the notion of mythmaking, as is the choice of including David's cycle in consideration of biblical myth.

With very little supernatural elements in its narrative, the story of David's rise and reign is often read as historiography. The fact that only between the lines one can detect a more sinister portrayal of an aggressive and opportunistic usurper only adds to the narrative's reception as historiography; ${ }^{62}$ that is to say, not necessarily a record of events as they happened, but perhaps a faithful account of how someone wanted actual occurrences to be remembered. Yet even with such objectives, the process of storytelling continues to develop and aesthetic choices assemble to create certain patterns. As several have noted, some of the stories about David were patterned after the patriarchal narratives, and others are stylized as entertaining folktales. The distinction between folklore and myth is in some cases quite obvious (e.g., riddles), but in others the line is quite blurry. ${ }^{63}$ In this context it is worthy to consider David as an epic hero, and to examine the mythical structure of his narrative, in relation to a likewise quasi-historical figure, $\mathrm{Lü} \mathrm{Bu}^{64}$

Lü Bu, also known as the "Flying General" (飛將), is noted for being a highly successful warrior, but also for his impulsive nature and disloyal conduct. ${ }^{65}$ Through his shifted alliances he plays an instrumental role in solidifying the different powers of his day, including his own, when he takes control over $\mathrm{Xu}$ province (徐州). Points of resemblance between his narrative and the David cycle alternate between similarities to David and similarities to Absalom. The way both the father and the son resonate with $\mathrm{LüBu}$ is in itself a valuable demonstration of the similarities between the two usurpers, David in regards to his father-in-law, and Absalom challenging his father. ${ }^{66}$ Among the many similarities are the following points:

- $\quad$ Lü Bu is noted for his conspicuous appearance, with a focus on his hair (Romance of the Three Kingdoms, chapter 3; cf. 1 Sam 16:12; 2 Sam 14:25-26). Both warriors are associated with the color red. ${ }^{67}$

58 Concerning the historicity of the work and the relation between the Records and the Romance, see (Tillman (2002, 2007)).

59 For the history of Christianity in China, see Bays (2012); Mungello (2012); Latourette (1929).

60 For its reception and place in Chinese culture, see McLaren (1995).

61 Thus, for example, by one of its earliest commentators, Mao Zonggang (毛宗崗; 1632-1709), who wrote a commentary on the work with his father, and highlights in his treatise the vast number of ministers, generals, and heroes in the Romance. See David Roy's translation in Rolston (1990, pp. 146-95).

62 For a cynical interpretation of David, as well as a survey of the question of his historicity, see McKenzie (2000). For more favorable portrayals, see Zakovitch (1995); Wolpe (2014). On the historiography of the Books of Samuel, see Brooks (2005, pp. 1-68); Gilmour (2011).

63 On the distinction and interplay between folklore and myth, see Kirkpatrick (1988, pp. 13-50); Niditch (1993, pp. 33-65); Dundes (1999, pp. 1-63). See also Yassif (1988).

64 For prior examples of studying the quasi-historical books of the Hebrew Bible as myth, see Brettler (1991); Vainstub (2011); Louden (2018, pp. 111-62).

65 de Crespigny (2007, pp. 624-25); Zhou (2006, p. 251); Wu (2017, pp. 56-68)Wu

66 Note also McKenzie (2000, pp. 153-73), who compares Absalom's betrayal of his father to David's betrayal of Uriah.

67 Later in the same chapter, Lü Bu's famed horse, called Red Hare, is also noted for its "uniform color like glowing-sun red-not a hair of another color". The comparison between them is made explicit in chapter 5, where it is stated that 
- Lü Bu assures his new master, Dong Zhuo (董卓), that he can win the battle for him (chapter 5), as David assured Saul (1 Sam 17:32). Like David, his proposal is greeted with skepticism (1 Sam 17:33), but unlike David, with Lü bu the source of skepticism is his great skill in war: "someone behind Lü Bu broke in upon his speech, saying, "An ox-cleaver to kill a chicken! there is no need for the General to go". 68

- When Wang Yun (王允) plots to entrap Lü Bu by offering his daughter in marriage, Lü Bu is taken aback by the honors showered upon him, and humbly responds, "I am but a simple officer in the palace of a minister" (Romance, chapter 8). This is reminiscent of David's response to the proposition to marry the king's daughter (1 Sam 18:23). In both cases there is reason to believe this is feigned humility rather than genuine modesty.

- In response to his humble reaction, $\mathrm{Lü} \mathrm{Bu}$ is reminded that he is a matchless hero: "in the whole land there is no hero your equal" (Romance, chapter 8), as was claimed about David (1 Sam 18:7, 21:12, 29:5). Similarly, Saul responds to David's reluctance to marry by suggesting that David demonstrate his skills as a warrior.

- When Dong Zhuo sees Lü Bu speaking to his wife intimately, he "hurled the halberd [towards him]. Lü Bu fended it off and it fell to the ground. Dong Zhuo picked it up and chased him" (Romance, chapter 8). While the impetus for the attack is starkly different, the scene is reminiscent of Saul's attack on David (1 Sam 18:10-11, 19:9-10). Later, Wang Yun will remind Lü Bu of this scene to question the relationship between them: "Where was the paternal feeling when he threw the halberd at you?" (Romance, chapter 9), just as David understands he needs to sever ties with his father-in-law.

- When Dong Zhuo is prepared to seize power, but is actually about to be killed by Lü Bu, it is mentioned that he slept in the midst of his escort (Romance, chapter 9), as is described about Saul during his pursuit against David (1 Sam 26:5). ${ }^{69}$

- In chapter 16 of the Romance, After Lü Bu ends the battle for Liu Bei through his archery, he begins to suspect Liu Bei, and hesitates regarding the right course of action. The intrigue between them, and the conflict with Cao Cao echoes many scenes from both Saul's pursuit of David and Absalom's rebellion. In particular, there are two scenes where a ruler (first Liu Bei, and then Cao Cao), receive two conflicting proposals from the advisors, as does Absalom (2 Sam 16:15-17:23).

Each of these points of comparison also includes important differences. In order to demonstrate the function of the inversion principle, we will examine more closely the story of Wang Yun's plot to cause a rift between Lü Bu and Dong Zhuo.

After Lü Bu betrays his master Ding Yuan and defects to Dong Zhuo's side, Wang Yun (王允) seeks to cause a rift between Lü Bu and Dong Zhuo in order to weaken them. He calls his adoptive daughter Diao Chan (貂蟬) ${ }^{70}$ one of the famed Four Beauties, and divulges his plan to her:

The people are on the brink of destruction, the prince and his officers are in jeopardy, and you, you are the only savior. That wretch Dong Zhuo wants to depose the Emperor, and not a person among us can find means to stop him. Now he has a son, a bold warrior, it is true, but both father and son have a weakness for beauty, and I am going to use what I may call

"indeed Lü Bu was the man among humans, as Red Hare was the horse among horses". Lü Bu is described wearing a headdress of "ruddy gold." Translations from the Romance quoted (with minor changes) from (Brewitt-Taylor 2002).

68 This motif, however, resurfaces later in the chapter, when another warrior, named Guan Yu, seeks to be sent to slay Hua Xiong. The initial response is, "Hua Xiong will laugh at us if we send a mere archer to fight him," quite reminiscent of Goliath's response in 1 Sam 17:43.

69 Gersonides comments on this verse that this is intended to instill fear in anyone approaching, and hence is a sign of both power and of fear, or at least concern for vulnerability. Contrast with Uriah's confident decision to sleep with his peers (2 Sam 11:8-13).

70 The motif of the guardian father exploiting the beauty of a young woman in his custody evokes the relationship of Mordecai and Esther (Es 2:5-20). We cannot expand on this here, but hope to return in the future to similarities between the narratives of Esther and of the four beauties, not only Diao Chan, but also Xi Shi. 
the 'chaining' plan. I shall first propose you in marriage to Lü Bu and then, after you are betrothed, I shall present you to Dong Zhuo, and you will take every opportunity to force them asunder and turn sway their countenances from each other, cause the son to kill his adopted father and so put an end to the great evil. Thus you may restore the altars of the land that it may live again. (Romance, chapter 8).

Diao Chan dutifully agrees and what follows is a sophisticated ruse whereby Lü Bu is led to believe that his patron Dong Zhuo was given Diao Chan merely in order to transport her to Lü Bu and then he took her for himself, while Dong Zhuo is completely oblivious that Diao Chan was promised to Lü Bu. Each time Diao Chan spends time alone with one of them, she assures her companion she loves only him, and has no interest in the other. Li Ru (李儒) is Dong Zhuo's son-in-law, who tries to reconcile between Dong Zhuo and $\mathrm{LüB} \mathrm{Bu}$, recognizing the threat their tension over Diao Chan poses to Dong Zhuo's rule. When he fails to resolve it, he casts his eyes to the heavens, saying, "We are dead people, slain by the hand of this girl!" (Romance, chapter 9).

The ruse parallels in an inverted manner the story of David's marriage to Saul's daughter: Saul's eldest daughter is promised to two men (1 Sam 18:19), and when Saul decides to give his younger daughter Michal to David, he obscurely pronounces: "by two you shall marry me today" (1 Sam 18:21). ${ }^{71}$ The peculiar brideprice Saul requests (1 Sam 18:25) indicates that the second marriage is likewise intended as a ruse. The inversion occurs in the shift of the scheming father: in the Romance the father of the daughter is seeking to create a rift between Dong Zhuo and $\mathrm{LüBu}$, who function as father and son. In David's story, the father of the daughter, Saul, is also the father-figure for the usurper.

This consolidation of roles creates an inversion with three main consequences: first of all, while Diao Chan - the daughter who is promised to the usurper-is loyal to her father and lies to both the usurper and the threatened leader, Michal lies to her father who is also the threatened leader, but remains loyal to the usurper (1 Sam 19:11-17). ${ }^{72}$ Second, Dong Zhuo dies in the hands of Lü $\mathrm{Bu}$, unable to decipher the many omens warning him of his impending doom (Romance, chapter 9). By contrast, Saul goes into battle fully aware of the fate that awaits him (1 Sam 28:19), and ultimately dies by his own hands (1 Sam 31:4). ${ }^{73}$

Finally, according to Lévi-Strauss's formulation of the inversion principle, it cannot be mere contrasts between narratives, but must include the reemergence of an omitted detail from one narrative in an inverted function in another. This is already found in the inverse role of Michal, but also evident in the consolidation of the two roles in the figure of Saul as an indication of the omitted detail. Table 3 serves to demonstrate:

Table 3. Structure of relationships in the narratives of a marriage ruse.

\begin{tabular}{|c|c|c|}
\hline Character's Function & Romance of the Three Kingdoms & Hebrew Bible \\
\hline $\begin{array}{l}\text { The plotter against the relationship of the } \\
\text { two leaders }\end{array}$ & Wang Yun & - \\
\hline Senior leader, current ruler & Dong Zhuo & Saul \\
\hline Junior leader, usurper & $\mathrm{Lü} \mathrm{Bu}$ & David \\
\hline Daughter promised to junior leader, as ploy & Diao Chan/-(second one absent) & Merab/Michal \\
\hline Conciliatory Son & $\mathrm{Li} \mathrm{Ru}$ & Jonathan \\
\hline
\end{tabular}

71 For the textual and grammatical problems of the phrase, see Segal (1976, p. 153); McCarter (1980, p. 316). Alter (1999, p. 116) prefers to translate idiomatically "through the second one," but summarizes well the options for the literal reading: two daughters, two conditions, or two reasons.

72 Herein lies Michal's tragedy: while she showed her loyalty to David when it was most crucial for him, she does not benefit from it. Throughout the narrative she continues "to be the victim of David's changing relationship with the house of Saul", as concisely stated by Bowman (1991, p. 108).

73 In this, of course, Saul is not only different from Dong Zhuo, but markedly from David, who avoids going to battle when his son Absalom rebels against him (2 Sam 18:1-5). 
$\mathrm{Li} \mathrm{Ru}$ and Jonathan are paralleled as son figures to the senior leader (Li Ru being Dong Zhuo's son-in-law), but their functions are inversed. Unlike Jonathan, Li Ru does not truly appreciate Lü Bu but seeks to appease him for the sake of preserving his father-in-law's power. Conversely, Jonathan genuinely seeks to defuse the conflict of Saul and David (1 Sam 19:4-7), even as he is working against his own interests (1 Sam 20:31). Li Ru is opposed to Diao Chan, unlike Jonathan whose relation to his sisters is never specified, although he is aligned with Michal as both are two unlikely allies of David. $\mathrm{Li} \mathrm{Ru}$ dies in the hands of Wang Yun, while Jonathan's death in battle is not explicitly presented as part of this plot. Jonathan's sincere reconciliatory position, combining both love for David and loyalty to his father is the inverted function of the absent role of Wang Yun. The motif of the external plotter in the Romance is absent from the narrative of Saul and David, and appears in an inverted function through intensely internal figures. Saul does the plotting himself in order to undermine David, rather than for the sake of severing their relations. However, the severing of their relations, with David's escape, is the beginning of Saul's downfall in the hands of the Philistines. More importantly, Jonathan is the inverse of the plotter: unlike Wang Yun, he is not external to the scene, but deeply rooted in it through his family connection to Saul and his deep friendship with David (1 Sam 18:1-3, 20:16-17; 2 Sam 1:26). His sincerity, and possibly even naïveté, stands in contrast to the devious character of Wang Yun. The absent plotter thus emerges in the function of appeasement, while Li Ru's efforts to appease remain a manipulative maneuver, a counterpart to Wang Yun.

There are other points of comparison between the various warriors depicted in the Romance of the Three Kingdoms and the biblical historiographic tales. Even in the brief scope of Lü Bu's relationship with Dong Zhuo, other characters display similarities, such as the brief scene with Cai Yong, who is caught weeping, rather than rejoicing, over the death of the rebel. Before he is punished, everyone begs Wang Yun to spare him (Romance, chapter 9), in a scene reminiscent of 1 Sam 14:45. ${ }^{74}$ The discussion here is far from exhaustive, but merely a demonstration of the benefits in store when expanding the subject of comparative research for biblical studies. These benefits will be summarized in the conclusion.

\section{Conclusions}

The inversion principle is certainly not the only element to be studied when examining a biblical myth. It is highlighted here not only since reference to it is commonly neglected, but mostly because it is a formalist feature that enables an almost technical assessment of a narrative as myth. Other common features such as incestuous and violent relationships and universal tensions between loyalty and ambition animate the texts we explored in ways that highlight the presence of mythical elements even in historiographic works. The manifestation of mythic elements in a historical narrative cannot, on its own, serve as evidence in the debate over a story's historicity. ${ }^{75}$

We divide our insights from this study into three main points: internal for each cultural context on its own; cross-cultural benefits of the comparison; and universal insights applicable to both texts and more broadly to the study of these literatures.

Internally, each pair of texts studied offers new insights on how these texts are understood. The narratives of Moses and David are not often compared to one another, owing to the distinct literary genres and themes of each of these protagonists. The connection between these narratives was not a focus of this article but drawing these pairs together for the shared theme of rebellion is intended to suggest further connections between them. Further consideration of the power struggles between

\footnotetext{
74 This parallel, too, appears in an inverted function, since unlike the plea to spare Jonathan, the plea is to no avail for Cai Yong, who is put to death. In turn, he himself is mourned, since the people "refused to see any offense in what he had done." The ending is thus more reminiscent of the story of Jephthah's daughter (Judges 11:40), pointing to further comparative work needed, discussing this narrative in relation to both Judges 11 and 1 Samuel 14. For a comparison of Saul's oath and Jephthah's vow, see Exum (1992, pp. 75-78).

75 Contra Hodge (2006).
} 
Moses and Aaron in light of more palpable power struggles as those between Saul and David may shed new light on Moses and the political aspects of his leadership. ${ }^{76}$

Similarly, Shiji and the Romance of the Three Kingdoms are not commonly compared, as they belong to vastly different periods and different genres. However, identifying mythical elements in them points to new directions in the study of the interplay of myth and history in these texts. Despite the considerable differences between these texts, the sections we examined both share the theme of the timeliness of attacks. It was discussed above in relation to the Shiji, but it also appears in the Romance. Just as Shiji wavers on this point, making an explicit claim for the benefits of the first move, but implicitly demonstrating the advantages of restraint and patience, so the Romance includes these conflicting tendencies. When Lü Bu considers betraying Ding Yuan and defecting to Dong Zhuo's side, Li Su (李肅) urges him to hasten: "such a thing must be done quickly" (Romance, chapter 3). After Lü Bu kills Dong Zhuo, however, a poem recited states: "Await the time, O noble, and be king" (Romance, chapter 9). Lü Bu himself embodies the double advice: indeed timing is everything, but there are cases where this implies swift action, and others when patience is advisable. The presence of this theme in two classic works of Chinese literature, so distinct in time and genre, in itself teaches something about the continuity of a tradition, the fundamental values embedded in these works, and the shared interest of historians and writers of historical fiction.

Cross-culturally, the joint examination of these works allows one to defamiliarize them and disrobe them of scholarly consensus so that they are seen in a fresh light. Biblical scholars and Sinologists alike are trained to think about their texts through certain paradigmatic lenses. Considering a new paradigm in which God is aligned as a ruler with Pharaoh, while Moses and Aaron are on the other side, is not an obvious approach that often emerges from the biblical text itself. Likewise, the curious detail of Xin being the only character in the Shiji who is reported to herd sheep for someone else has not drawn prior attention, and was highlighted only through the choice to compare distant cultures. Our methodology does not insist that these comparisons be between biblical and Chinese texts, but rather promises that a range of comparisons between works perceived as dissimilar to the core holds in store unimaginable possibilities. In the words of Longxi Zhang,

once the Other is understood as so real and concrete an existence as my neighbor, then differences between the self and the Other are put in perspective, a certain common ground emerges underneath the alterity and particularities, and it becomes impossible for me to deny the humanity of the Other as my neighbor. ${ }^{77}$

In this context, Zhang also quotes Gadamer's imperative of education, namely, "keeping oneself open to what is other-to other, more universal points of view" ${ }^{78}$ In the same spirit, we conclude with some universal insights that arose from our joint inspection of these texts.

One thing that struck us is the intense discrepancy between fundamental values in each respective culture and the conduct of famed leaders in the epic and mythical writings. This is true of Moses, who begins his public career by violating the biblical taboo on homicide, just as it is true of David, the father of the revered royal dynasty in ancient Israel, who commits adultery with Bathsheba, the mother of this dynasty. Likewise, the tales of Xiang Liang and of Lü Bu celebrate heroes who depart from the value of loyalty and filial duty. ${ }^{79}$ These discrepancies, in both cultures, suggest a new nuance to be

\footnotetext{
76 Studies of political aspects of Moses's leadership have not tended to compare him to David. Aaron Wildavsky briefly offers such a comparison noting the difference between Moses's rule and a monarch (Wildavsky 1984, pp. 256-57). Michael Walzer, even when considering Moses as monarch does not draw such a comparison (Walzer 1985, pp. 59-60). See also Keren (1988); Frymer-Kensky (1985)Frymer-Kensky

77 Zhang (1998, p. 26).

78 (Gadamer (Gadamer 2004, p. 15), and see Zhang's comments on this (Zhang 1998, pp. 51-54).

79 See Roberts (2020, pp. 392-400); Nylan (Nylan 1998-1999, pp. 208, 221-22, 236); L'Haridon (2015); Xin (2019). For the significance of filial piety in Chinese culture in general, see Holzman (1998); Chan and Tan (2004).
} 
added to the old notion of myth and ritual. ${ }^{80}$ On the one hand, myth indeed provides a rationale for certain rites or a background story of supposed origin, while the ritual often serves as a way to transmit and retell the myth. But the relationship between them is not one of complete correlation: the ritual often establishes and affirms certain laws and values, while the myth relishes their defiance. Just as the Chinese stories we examined offered an ambivalent approach to the question of the first-move as opposed to patience, so the study of myth reveals a tension that is deeply religious, simultaneously supporting the legal and ethical dimension of a given doctrine, while providing an entertaining outlet for its performative violation.

Another shared insight that rises from these texts is the double-edged sword of the figure of the rebel. Rebels, it appears, do not direct their rebellion to a limited and defined object when it is politically advantageous. This is rather a strong trait of character. Thus Moses's hesitation to accept the mission, leading to God's anger, is not only a prime example of the hero's refusal of the call. ${ }^{81}$ It is also a clear indication for God that this is the right candidate for the mission. If he is able to answer back to God, he will be able to talk back to Pharaoh, too. At the same time, it also harbingers Moses's own defiance of God's wishes, as noted above. Similarly, Dong Zhuo brings his own downfall upon himself, by approving the plan to tempt $\mathrm{Lü} \mathrm{Bu}$ to cross the lines and defect to his camp. The structure of the narrative implies that by coming into proximity with a known traitor, who betrays his loyalties so easily, Dong Zhuo put himself in danger. Dong Zhuo could have known that Lü Bu might betray him precisely because of the manner in which Lü Bu was convinced to join him. David, too, should have known that the challenge he presents to the rule of Saul means that one day his own power would be challenged. ${ }^{82}$ Since he was like a son to Saul, the replication of the threat in the form of David's own son intensifies the same idea of a fated repetition. The theme of the deceiver who is duped, which runs through the biblical tales of both Jacob and David, ${ }^{83}$ repeats itself in several interactions of Dong Zhuo and Lü Bu, with the conflict over Diao Chan in between.

Another shared theme between these texts is the question of the higher cause. When David mourns the death of Absalom, Joab rebukes him, explaining that the death of Absalom was necessary to end the mutiny, to restore the peace, and to spare the nation (2 Sam 19:6-8; cf. 2 Sam 18:16). Chapter 5 of the Romance of the Three Kingdoms, concludes with the advice, "to quell a rebellion, seize the leader, if you are able". Earlier, when Dong Zhuo wishes to justify his own rebellion, he uses two metaphors to convey the same idea:

to stop the ebullition of a pot the best way is to withdraw the fire; to cut out an abscess, though painful, is better than to nourish the evil. I have dared undertake a military advance on the capital, with your permission (Romance, chapter 3).

Yair Zakovitch has persuasively shown how this same idea also dictates the story of Absalom, and that the story of Absalom was fashioned after the story of the Binding of Isaac in order to convey this point. ${ }^{84}$ Abraham, who was willing to sacrifice his son for a higher purpose, has his son spared and gains God's graces; David, who preferred his son to be spared at the price of losing his power, has to learn the same lesson of the importance of sacrifice through the loss of his son.

Comparisons have a variety of objectives. The comparative approach in biblical studies tends to focus on the search for origins: of narratives, of laws, of words. Other comparisons have stressed

80 For some introductory comments on the myth and ritual method, see Masuzawa (1993, pp. 21-30); Strenski (1996); Ackerman (1998).

81 On this trope see Campbell (Campbell 2004, pp. 54-63).

82 In the same vein, David Kimhi notes on Saul's inquiry about David's ancestry after he defeats Goliath (1 Sam 17:55) that it betrays a concern, or rather an awareness, that David's manifest strength is also a threat on his kingdom. Alter (1999, pp. 110-11) shows how the redactional problem of the question introduces new literary and psychological perspectives on Saul and David.

83 See Marcus (1986).

84 Zakovitch (1982). See also on David's fatherhood in general, idem (David 1996, pp. 85-95); Wolpe (2014, pp. 89-117). 
universal themes. The flood narrative is a known example for these diverse ventures: by comparing the Sumerian and Babylonian flood myths to Noah's narrative in Genesis, it is possible to identify a direct influence that contributed to the formation of biblical narrative. ${ }^{85}$ Comparisons to other flood myths are another level of comparison, that do not point to origins, but rather allow the shared details to illuminate universal themes that resurface in biblical literature. ${ }^{86}$ Reception history and exegetical studies trace further adaptations and developments of the initial myth as it continues to travel in place and time. ${ }^{87}$ Finally, we offer here a fourth route of comparison, that is distinct from these other three, and sheds new light on structure and message of the biblical narrative, while simultaneously using the biblical text to elucidate Chinese texts and yield insights in both directions of the comparison.

Author Contributions: Both authors contributed equally to this work. Both authors have read and agreed to the published version of the manuscript.

Funding: This research received no external funding.

Conflicts of Interest: The authors declare no conflict of interest.

\section{References}

Ackerman, Robert. 1998. J. G. Frazer and the Cambridge Ritualists and the 'Scientific' Study of Religion. In Religion in the Making: The Emergence of the Sciences of Religion. Edited by Arie L. Molendijk and Peter Pels. Leiden: Brill, pp. 129-58.

Ah, Ertai. 2015. A Comparison between Genesis in Bible and the Creation in Mongolia Myths. China Extracurricular Education 2: 26, 29. (In Chinese)

Allen, Douglas. 2002. Myth and Religion in Mircea Eliade. New York: Routledge.

Alter, Robert. 1999. The David Story. New York: Norton.

Amihay, Aryeh. 2018. Biblical Myths and the Inversion Principle: A Neostructuralist Approach. Journal of Biblical Literature 137: 555-79. [CrossRef]

Asano, Atsuhiro. 2011. Uchimura and the Bible in Japan. In The Oxford Handbook of the Reception History of the Bible. Edited by Michael Lieb, Emma Mason and Jonathan Roberts. Oxford: Oxford University Press, pp. 323-39.

Assmann, Jan. 1997. Moses the Egyptian: The Memory of Egypt in Western Monotheism. Cambridge: Harvard University Press.

Astour, Michael C. 1965. Hellenosemitica: An Ethnic and Cultural Study in West Semitic Impact on Mycenaean Greece. Leiden: Brill.

Baden, Joel S. 2019. The Book of Exodus: A Biography. Princeton: Princeton University Press.

Ballentine, Debra. 2015. The Conflict Myth and the Biblical Tradition. Oxford: Oxford University Press.

Bartsch, Shadi. 2013. The Ancient Greeks in Modern China: History and Metamorphosis. In Receptions of Greek and Roman Antiquity in East Asia. Edited by Almut-Barbara Renger and Xin Fan. Leiden: Brill, pp. 237-56.

Bays, Daniel H. 2012. A New History of Christianity in China. Malden: Wiley-Blackwell.

Bin, You. 2011. Comparative Scriptural Studies as an Approach of Doing Biblical Studies in China: Taking Zhu Xi's 'Scripture Reading Strategy as a Case Study'. Gregorianum 92: 665-86.

Bowman, Richard G. 1991. The Fortune of King David/The Fate of Queen Michal: A Literary Critical Analysis of 2 Samuel 1-8. In Telling Queen Michal's Story: An Experiment in Comparative Interpretation. Edited by David J. A. Clines and Tamara C. Eskenazi. Sheffield: JSOT Press, pp. 97-120.

Bray, Jason S. 2006. Sacred Dan: Religious Tradition and Cultic Practice in Judges 17-18. New York: T\&T Clark. Breed, Brennan W. 2014. Nomadic Text: A Theory of Biblical Reception History. Bloomington: Indiana University Press. Brettler, Marc. 1991. Never the Twain Shall Meet? The Ehud Story as History and Literature. Hebrew Union College Annual 62: 285-304.

85 See Dundes (1988, pp. 29-87); Rendsburg (2007); Wasserman (2020).

86 See examples in Dundes (1988, pp. 183-317).

87 See, for example, in Martínez and Luttikhuizen (1999); Stone et al. (2010). 
Brewitt-Taylor, C. H. 2002. Romance of the Three Kingdoms by Lo Kuan-Chung. North Clarendon: Tuttle, First Publish in 1959.

Brooks, Simcha Shalom. 2005. Saul and the Monarchy: A New Look. Aldershot: Ashgate.

Campbell, Joseph. 2004. The Hero with a Thousand Faces. Princeton: Princeton University Press, First Publish in 1949.

Chan, Alan K. L., and Sor-hoon Tan, eds. 2004. Filial Piety in Chinese Thought and History. London: Routledge.

Chavalas, Mark W. 2011. The Comparative Use of Ancient Near Eastern Texts in the Study of the Hebrew Bible. Religion Compass 5: 150-65. [CrossRef]

Chen, Yiyi. 2008. The Developing Role of the Hebrew Bible in Modern China. In The Jewish-Chinese Nexus: A Meeting of Civilizations. Edited by M. Avrum Ehrlich. London: Routledge, pp. 152-63.

Childs, Brevard S. 1974. The Book of Exodus: A Critical, Theological Commentary. Philadelphia: Westminster Press. Cho, Paul K.-K. 2019. Myth, History and Metaphor in the Hebrew Bible. Cambridge: Cambridge University Press.

Collins, John J. 1979. The 'Historical Character' of the Old Testament in Recent Biblical Theology. Catholic Biblical Quarterly 41: 185-204.

Collins, Andrew. 2014. The Divinity of the Pharaoh in Greek Sources. Classical Quarterly 64: 841-44. [CrossRef]

Cross, Frank Moore. 1973. Canaanite Myth and Hebrew Epic: Essays in the History of the Religion of Israel. Cambridge: Harvard University Press.

Darshan, Guy. 2018. After the Flood: Stories of Origins in the Hebrew Bible and Eastern Mediterranean Literature. Jerusalem: Bialik Institute. (In Hebrew)

David, Alun. 1996. Sir William Jones, Biblical Orientalism and Indian Scholarship. Modern Asian Studies 30: 173-84. [CrossRef]

de Crespigny, Rafe. 2007. A Biographical Dictionary of Later Han to the Three Kingdoms (23-220 AD). Leiden: Brill.

Denecke, Wiebke. 2014. Classical World Literatures: Sino-Japanese and Greco-Roman Comparisons. Oxford: Oxford University Press.

Douglas, Christopher. 2009. A Genealogy of Literary Multiculturalism. Ithaca: Cornell University Press.

Dozeman, Thomas B. 2009. Exodus. Grand Rapids: Eerdmans.

Dundes, Alan, ed. 1988. The Flood Myth. Berkeley: University of California Press.

Dundes, Alan. 1999. Holy Writ as Oral Lit: The Bible as Folklore. Lanham: Rowman and Littlefield.

Durrant, Stephen W. 1995. The Cloudy Mirror: Tension and Conflict in the Writings of Sima Qian. Albany: State University of New York Press.

Eber, Irene, Sze-kar Wan, and Knut Walf, eds. 1999. The Bible in Modern China: The Literary and Intellectual Impact. Sankt Augustin: Monumenta Serica Institute.

England, Emma, and William John Lyons, eds. 2015. Reception History and Biblical Studies: Theory and Practice. London: T\&T Clark.

Exum, J. Cheryl. 1992. Tragedy and Biblical Narrative: Arrows of the Almighty. Cambridge: Cambridge University Press.

Fishbane, Michael. 2005. Biblical Myth and Rabbinic Mythmaking. Oxford: Oxford University Press.

Flynn, Shawn W. 2013. YHWH Is King: The Development of Divine Kingship in Ancient Israel. Leiden: Brill.

Frymer-Kensky, Tikva. 1985. Moses and the Cults: The Question of Religious Leadership. Judaism 34: 444-52.

Gadamer, Hans-Georg. 2004. Truth and Method, 2nd ed. Translated by Joel Weinsheimer, and Donald G. Marshall. London: Continuum, First Publish in 1975.

Gálik, Marián. 2004. Influence, Translation, and Parallels: Selected Studies on the Bible in China. Sankt Augustin: Monumenta Serica Institute.

Gálik, Marián. 2010. Hebrew Deuteronomistic and Early Chinese Confucian Historiography: A Comparative Approach. Frontiers of History in China 5: 343-62. [CrossRef]

Gelander, Shamai. 2018. And Behold, It Was Very Good: God and Humanity in Genesis 1-11. Tel Aviv: Resling. (In Hebrew)

Gilmour, Rachelle. 2011. Representing the Past: A Literary Analysis of Narrative Historiography in the Book of Samuel. Leiden: Brill.

Gordon, Cyrus H. 1955. Homer and the Bible: The Origin and Character of East Mediterranean Literature. Hebrew Union College Annual 26: 43-108.

Greenspahn, Frederick E., ed. 1991. Essential Papers on Israel and the Ancient Near East. New York: New York University Press.

Guillaume, Ph. 2004. Metamorphosis of a Ferocious Pharaoh. Biblica 85: 232-36. 
Hardy, Grant. 1994. Can an Ancient Chinese Historian Contribute to Modern Western Theory? The Multiple Narratives of Ssu-Ma Ch'ien. History and Theory 33: 20-38. [CrossRef]

Hare, Tom. 1999. Remembering Osiris: Number, Gender, and the Word in Ancient Egyptian Representational Systems. Stanford: Stanford University Press.

Hausken, Kjell. 2011. Strategic Defense and Attack of Series Systems When Agents Move Sequentially. IIE Transactions 43: 483-504. [CrossRef]

Hendel, Ronald, ed. 2010. Reading Genesis: Ten Methods. Cambridge: Cambridge University Press.

Hodge, Joel. 2006. 'Dead or Banished': A Comparative Reading of the Stories of King Oedipus and King David. Scandinavian Journal of the Old Testament 20: 189-215. [CrossRef]

Holdrege, Barbara A. 1996. Veda and Torah: Transcending the Textuality of Scripture. Albany: State University of New York Press.

Holzman, Donald. 1998. The Place of Filial Piety in Ancient China. Journal of the American Oriental Society 118: 185-99. [CrossRef]

$\mathrm{Hu}$, Jiangqing. 2014. A Comparison of Love Songs in Guofeng of the Book of Odes and Song of Songs in the Bible. Sehn Zhou 2: 5. (In Chinese).

Hulsewé, A. F. P. 1975. The Problem of the Authenticity of Shih Chi ch. 123, the Memoir on Ta Yüan. T'oung Pao 61: 83-147. [CrossRef]

Jullien, François. 2000. Detour and Access: Strategies of Meaning in China and Greece. Translated by Sophie Hawkes. New York: Zone.

Kaufmann, Walter. 1958. Critique of Religion and Philosophy. Princeton: Princeton University Press.

Keren, Michael. 1988. Moses as a Visionary Realist. International Political Science Review 9: 71-84. [CrossRef]

Kerin, Roger A., P. Rajan Varadarajan, and Robert A. Peterson. 1992. First-Mover Advantage: A Synthesis, Conceptual Framework, and Research Propositions. Journal of Marketing 56: 33-52. [CrossRef]

Kern, Martin. 2003. The 'Biography of Sima Xiangru' and the Question of the Fu in Sima Qian's Shiji. Journal of the American Oriental Society 123: 303-16. [CrossRef]

Kern, Martin. 2015. The 'Masters' in the Shiji. T'oung Pao 101: 335-62. [CrossRef]

Kidd, Samuel. 1841. China. London: Taylor \& Walton.

Kim, Andrew W. 2000. Korean Religious Culture and Its Affinity to Christianity: The Rise of Protestant Christianity in South Korea. Sociology of Religion 61: 117-33. [CrossRef]

Kirkpatrick, Patricia G. 1988. The Old Testament and Folklore Study. Sheffield: JSOT Press.

Klauck, Hans-Josef, ed. 2009. Encyclopedia of the Bible and Its Reception, Volume 1: Aaron-Aniconism. Berlin: de Gruyter.

Klein, Esther Sunkyung. 2019. Reading Sima Qian from Han to Song: The Father of History in Pre-Modern China. Leiden: Brill.

Koosed, Jennifer L. 2016. The Cinematic Moses. In The Bible in Motion: A Handbook of the Bible and Its Reception in Film. Edited by Rhonda Burnette-Bletsch. Berlin: de Gruyter, pp. 65-82.

Kugel, James L. 1998. Traditions of the Bible: A Guide to the Bible as It Was at the Start of the Common Era. Cambridge: Harvard University Press.

Kunin, Seth Daniel. 1995. The Logic of Incest: A Structuralist Analysis of Hebrew Mythology. Sheffield: Sheffield Academic Press.

L'Haridon, Béatrice. 2015. The Merchants in Shiji: An Interpretation in the Light of Later Debates. In Views from Within, Views from Beyond: Approaches to the Shiji as an Early Work of Historiography. Edited by Hans van Ess, Olga Lomová and Dorothee Schaab-Hanke. Wiesbaden: Harrassowitz, pp. 171-91.

Larsen, Mognes Trolle. 1995. The ‘Babel/Bible' Controversy and Its Aftermath. In Civilizations of the Ancient near East. Edited by Jack M. Sasson. New York: Scribner, pp. 95-106.

Latourette, Kenneth Scott. 1929. A History of Christian Missions in China. New York: Macmillan.

Legge, James. 1882. The Sacred Books of China: The Texts of Confucianism; Part II: The Yî King. Oxford: Clarendon.

Legge, James. 1885a. The Sacred Books of China: The Texts of Confucianism; Part III: The Lî Kî, I-X. Oxford: Clarendon. Legge, James. 1885b. The Sacred Books of China: The Texts of Confucianism; Part IV: The Lî Kî, XI-XLVI. Oxford: Clarendon. Lévi-Strauss, Claude. 1955. The Structural Study of Myth. Journal of American Folklore 68: 428-44. [CrossRef] Lévi-Strauss, Claude. 1963. Structural Anthropology. Translated by Claire Jacobson, and Brooke Grundfest Schoepf. New York: Basic Books.

Lewis, Mark Edward. 1999. Writing and Authority in Early China. Albany: State University of New York Press. 
Li, Ting Yuen. 2007. Date of Composition, Evolution of Edition, and Authorship of the Romance of the Three Kingdoms as Seen from Two Plots. Journal of Chinese Studies 47: 313-34. (In Chinese).

Lieb, Michael, Emma Mason, and Jonathan Roberts, eds. 2011. The Oxford Handbook of the Reception History of the Bible. Oxford: Oxford University Press.

Liu, Qinghe. 1987. Exploring Several Laws of Oriental Literature by Comparing the Old Testament and Shiji. Journal of Hanzhong Normal Institute 3: 25-31. (In Chinese).

Lloyd, G. E. R. 2014. The Ideals of Inquiry: An Ancient History. Oxford: Oxford University Press.

Louden, Bruce. 2018. Greek Myth and the Bible. London: Routledge.

Magee, Joe C., Adam D. Galinsky, and Deborah H. Gruenfeld. 2007. Power, Propensity to Negotiate, and Moving First in Competitive Interactions. Personality and Social Psychology Bulletin 33: 200-12. [CrossRef]

Malul, Meir. 1990. The Comparative Method in Ancient Near Eastern and Biblical Legal Studies. Kevelaer: Butzon \& Bercker. Marcus, David. 1986. David the Deceiver and David the Dupe. Prooftexts 6: 163-71.

Martínez, Florentino García, and Gerard P. Luttikhuizen, eds. 1999. Interpretations of the Floods. Leiden: Brill.

Masuzawa, Tomoko. 1993. In Search of Dreamtime: The Quest for the Origin of Religion. Chicago: University of Chicago Press.

Masuzawa, Tomoko. 2005. The Invention of World Religions, or, How European Universalism Was Preserved in the Language of Pluralism. Chicago: University of Chicago Press.

McCarter, P. Kyle, Jr. 1980. I Samuel. New York: Doubleday.

McKenzie, Steven L. 2000. King David: A Biography. Oxford: Oxford University Press.

McLaren, Anne E. 1995. Ming Audiences and Vernacular Hermeneutics: The Uses of the Romance of the Three Kingdoms. T'oung Pao 81: 51-80. [CrossRef]

Meng, Zhenhua. 2018. The Akedah and 'Guo Ju Buries His Son' 郭巨埋儿: A Cross-Textual Reading. Journal of Chinese Philosophy 45: 157-74. [CrossRef]

Meyers, Carol. 2005. Exodus. Cambridge: Cambridge University Press.

Milgrom, Jacob. 1990. Numbers. Philadelphia: Jewish Publication Society.

Milstein, Sara J. 2016. Tracking the Master Scribe: Revision through Introduction in Biblical and Mesopotamian Literature. Oxford: Oxford University Press.

Moore, Anne. 2009. Moving Beyond Symbol and Myth: Understanding the Kingship of God of the Hebrew Bible through Metaphor. Frankfurt am Main: Peter Lang.

Mulder, Martin Jan, ed. 1988. Mikra: Text, Translation, Reading and Interpretation of the Bible in Ancient Judaism and Early Christianity. Assen: van Gorcum.

Mungello, D. E. 2012. Reinterpreting the History of Christianity in China. Historical Journal 55: 533-52. [CrossRef]

Niditch, Susan. 1993. Folklore and the Hebrew Bible. Minneapolis: Fortress Press.

Niditch, Susan, ed. 2016. The Wiley Blackwell Companion to Ancient Israel. West Sussex: Wiley.

Nienhauser, William H., Jr., ed. 1994. The Grand Scribe's Records: Volume 1; The Basic Annals of Pre-Han China by Ssu-ma Ch'ien. Bloomington: Indiana University Press.

Nienhauser, William H., Jr. 2007. For Want of a Hand: A Note on the 'Hereditary House of Jin' and Sima Qian's 'Chunqiu'. Journal of the American Oriental Society 127: 229-47.

Nissinen, Martti, ed. 2000. Prophecy in Its Ancient Near Eastern Context: Mesopotamian, Biblical and Arabian Perspectives. Atlanta: Society of Biblical Literature.

Nylan, Michael. 1998-1999. Sima Qian: A True Historian? Early China 23-24: 203-46.

Olberding, Garret P. S. 2012. Dubious Facts: The Evidence of Early Chinese Historiography. Albany: State University of New York Press.

Payne, Elizabeth. 1964. The Pharaohs of Ancient Egypt. New York: Random House.

Plaks, Andrew H. 1987. The Four Masterworks of the Ming Novel: Ssu ta ch'i-shu. Princeton: Princeton University Press.

Propp, William H. C. Propp. 1999. Exodus 1-18. New York: Doubleday.

Quack, Joachim Friedrich. 2010. How Unapproachable is a Pharaoh? In Concepts of Kingship in Antiquity. Edited by Giovanni B. Lanfranchi and Robert Rollinger. Winona Lake: Eisenbrauns, pp. 1-14.

Rajkumar, Peniel. 2010. 'How' Does the Bible Mean? The Bible and Dalit Liberation in India". Political Theology 11: 410-30. [CrossRef]

Raphals, Lisa. 1992. Knowing Words: Wisdom and Cunning in the Classical Traditions of China and Greece. Ithaca: Cornell University Press. 
Rendsburg, Gary A. 2007. The Biblical Flood Story in the Light of the Gilgameš Flood Account. In Gilgameš and the World of Assyria. Edited by Joseph Azize and Noel Weeks. Leuven: Peeters, pp. 115-27.

Roberts, J. J. M. 1973. The Davidic Origin of the Zion Tradition. Journal of Biblical Literature 92: 329-44. [CrossRef] Roberts, J. J. M. 1976. Myth versus History: Relaying the Comparative Foundations. Catholic Biblical Quarterly 38: 1-13.

Roberts, J. J. M. 2002. The Bible and the Ancient near East: Collected Essays. Winona Lake: Eisenbrauns.

Roberts, Moss. 2020. Three Kingdoms: A Historical Novel. Oakland: University of California Press.

Rolston, David L., ed. 1990. How to Read the Chinese Novel. Princeton: Princeton University Press.

Sandmel, Samuel. 1962. Parallelomania. Journal of Biblical Literature 81: 1-13. [CrossRef]

Sasson, Vanessa R. 2007. The Birth of Moses and the Buddha: A Paradigm for the Comparative Study of Religions. Sheffield: Sheffield Phoenix Press.

Scheidel, Walter, ed. 2009. Rome and China: Comparative Perspectives on Ancient World Empires. Oxford: Oxford University Press.

Segal, M. H. 1976. The Books of Samuel. Jerusalem: Kiryat-Sepher. (In Hebrew)

Segal, Alan F. 2012. Sinning in the Hebrew Bible: How the Worst Stories Speak for Its Truth. New York: Columbia University Press.

Shankman, Steven, and Stephen Durrant, eds. 2002. Early China/Ancient Greece: Thinking Through Comparisons. Albany: State University of New York Press.

Silverman, Jason M. 2010. On Religious and Cultural Influence. In A Land like Your Own: Traditions of Israel and Their Reception. Edited by Jason M. Silverman. Eugene: Wipf and Stock, pp. 1-12.

Smart, Ninian. 1996. Dimensions of the Sacred: An Anatomy of the World's Beliefs. Berkeley: University of California Press. Smith, Jonathan Z. 2004. Relating Religion: Essays in the Study of Religion. Chicago: University of Chicago Press.

Spivak, Gayatri Chakravorty. 2012. An Aesthetic Education in the Era of Globalization. Cambridge: Harvard University Press.

Steinmetz, Devora. 1991. From Father to Son: Kinship, Conflict, and Continuity in Genesis. Louisville: Westminster/John Knox Press.

Stone, Michael E., Aryeh Amihay, and Vered Hillel, eds. 2010. Noah and His Book(s). Atlanta: Society of Biblical Literature.

Strenski, Ivan. 1996. The Rise of Ritual and the Hegemony of Myth: Sylvain Lévi, the Durkheimians, and Max Müller. In Myth and Method. Edited by Laurie L. Patton and Wendy Doniger. Charlottesville: University Press of Virginia, pp. 52-81.

Stuurman, Siep. 2008. Herodotus and Sima Qian: History and the Anthropological Turn in Ancient Greece and Han China. Journal of World History 19: 1-40. [CrossRef]

Sugirtharajah, R. S. 2018. Jesus in Asia. Cambridge: Harvard University Press.

Talmon, Shemaryahu. 1993. Literary Studies in the Hebrew Bible: Form and Content. Jerusalem: Magnes.

Taves, Ann. 2011. 'Religion' in the Humanities and the Humanities in the University. Journal of the American Academy of Religion 79: 287-314. [CrossRef]

Taylor, Charles. 2007. A Secular Age. Cambridge: Belknap.

Teng, S. Y. 1961. Herodotus and Ssu-ma Ch'ien: Two Fathers of History. East and West 12: 233-40.

Tillman, Hoyt Cleveland. 2002. Historic Analogies and Evaluative Judgments: Zhuge Liang as Portrayed in Chen Shou's 'Chronicle of the Three Kingdoms' and Pei Songzhi's Commentary. Oriens Extremus 43: 60-70.

Tillman, Hoyt Cleveland. 2007. Selected Historical Sources for Three Kingdoms: Reflections from Sima Guang's and Chen Liang's Reconstructions of Kongming's Story. In Three Kingdoms and Chinese Culture. Edited by Kimberly Besio and Constantine Tung. Albany: State University of New York Press, pp. 53-69.

Trimm, Charles. 2012. Recent Research on Warfare in the Old Testament. Currents in Biblical Research 10: 171-26. [CrossRef]

Trimm, Charles. 2017. Fighting for the King and the Gods: A Survey of Warfare in the Ancient near East. Atlanta: Society of Biblical Literature.

Trimm, Charles. 2019. God's Staff and Moses' Hand(s): The Battle against the Amalekites as a Turning Point in the Role of the Divine Warrior. Journal for the Study of the Old Testament 44: 198-214. [CrossRef]

Tsevat, Matitiahu. 1980. The Meaning of the Book of Job and Other Biblical Studies. New York: Ktav.

Tugendhaft, Aaron. 2018. Baal and the Politics of Poetry. London: Routledge. 
Vainstub, Daniel. 2011. Some Points of Contact between the Biblical Deborah War Traditions and Some Greek Mythologies. Vetus Testamentum 61: 324-34. [CrossRef]

von Clausewitz, Carl. 1976. On War. Translated by Michael Howard, and Peter Paret. Princeton: Princeton University Press, First Publish in 1832.

Waley, Arthur. 1937. The Book of Songs. London: Allen \& Unwin.

Walzer, Michael. 1985. Exodus and Revolution. New York: Basic Books.

Wasserman, Nathan. 2020. The Flood: The Akkadian Sources. Leuven: Peeters.

Weinfeld, Moshe. 1995. Social Justice in Ancient Israel and in the Ancient near East. Minneapolis: Fortress Press.

Weitzman, Steven. 1999. Reopening the Case of the Suspiciously Suspended Nun in Judges 18:30. Catholic Biblical Quarterly 61: 448-60.

Weitzman, Steven. 2016. Text and Context in Biblical Studies: A Brief History of a Troubled Relationship. In The Wiley-Blackwell Companion to Ancient Israel. Edited by Susan Niditch. Malden: Wiley-Blackwell, pp. 67-83.

Whedbee, J. William. 1998. The Bible and the Comic Vision. Cambridge: Cambridge University Press.

Wildavsky, Aaron. 1984. The Nursing Father: Moses as a Political Leader. Tuscaloosa: University of Alabama Press. Wilson, Ian D. 2017. Kingship and Memory in Ancient Judah. Oxford: Oxford University Press.

Wolpe, David. 2014. David: The Divided Heart. New Haven: Yale University Press.

Wu, Leijia. 2017. A Contribution to the Study on Sanguo Yanyi: Its Political Standpoint, Character Evaluation, and Character Development. Monumenta Serica 65: 43-60.

Xie, Guishan. 2019. Hebrew Ethics of Bible and Ethics and Pre-Qin Confucianism. Jinan: Shandong University Press. (In Chinese)

Xin, Zhaokun. 2019. A Fatal Encounter: Anger, Ritual, and Righteousness in the Romance of the Three Kingdoms. Chinese Literature 41: 1-24.

Yassif, Eli. 1988. Traces of Folk Traditions of the Second Temple Period in Rabbinic Literature. Journal of Jewish Studies 39: 212-33. [CrossRef]

Zakovitch, Yair. 1982. More on the Ram Caught in the Thicket. Tarbiz 52: 143-44. (In Hebrew).

Zakovitch, Yair. 1985. Mirror Narrative: Another Dimension for the Valuation of Characters in Biblical Narrative. Tarbiz 54: 165-76. (In Hebrew).

Zakovitch, Yair. 1995. David: From Shepherd to Messiah. Jerusalem: Yad Ben-Zvi. (In Hebrew)

Zhang, Lixin. 1999. The Connotation of Holiness: A Comparative Study of Shijing and the Bible. Kunming: Yunnan University Press. (In Chinese)

Zhang, Longxi. 1998. Mighty Opposites: From Dichotomies to Differences in the Comparative Study of China. Stanford: Stanford University Press.

Zhang, Longxi. 2010. Unexpected Affinities: Reading across Cultures. Cambridge: Cambridge University Press.

Zhang, Yanyong. 2018. A Comparison on the Filial Piety Concept: A Study on Texts of the Analects and the Bible. Course Education Research 34: 13-14. (In Chinese).

Zhou, Jianyu. 2006. Between Hero and Beauty: A Cultural Construction of Emotion in Sanguo yanyi (The Romance of the Three Kingdoms). In From Skin to Heart: Perceptions of Emotion and Bodily Sensations in Traditional Chinese Literature. Edited by Paolo Santangelo and Ulrike Middendorf. Wiesbaden: Harrassowitz, pp. 249-59.

Zurndorfer, Harriet T. 1995. China Bibliography: A Research Guide to Reference Works about China Past E Present. Leiden: Brill.

Publisher's Note: MDPI stays neutral with regard to jurisdictional claims in published maps and institutional affiliations.

(C) 2020 by the authors. Licensee MDPI, Basel, Switzerland. This article is an open access article distributed under the terms and conditions of the Creative Commons Attribution (CC BY) license (http://creativecommons.org/licenses/by/4.0/). 